\title{
Gymnastik og sanselighed
}

\author{
af Maj-Britt Nørgaard
}

\section{Optakt}

Gymnastikkens påvirkelighed idag er af mange slags, f.eks.: kunstnerisk, terapeutisk, pædagogisk, kommerciel, idrætslig, musisk med flere. Det interessante ved denne opremsning er, at gymnastikkens oprindelige udgangspunkt, det rent rationelle, der fandt sin begrundelse i det anatomiske og fysiologiske, idag er blevet udrangeret af andre (tidsbestemte) normdannere. Det »øvelseskaos«, der er kommet ud af dette, af at blande rationelt begrundede $\emptyset$ velser med irrationelle sider af tilværelsen, er en del af gymnastikkens forandring.

En forandring hvis afsmittende effekt på de gymnastiske traditioner, det dog kan være svært at få øje på. Ihvertfald er det ikke nemt at finde nytænkningen, finde visionerne i gymnastikken i dag.

Dette essay er et fors $\varnothing \mathrm{g}$ på at give ideer til denne forandring og nytænkning.

\footnotetext{
Åh.

Jeg vil forføres, betages og besættes.

Hvem tror for alvor på idræt som sundhed, idræt som ydre præstation?

Jeg vil rystes og flyttes - opleve.

Jeg vil bruge min krop, jeg vil danse, synge og le, meditere, transcendere.

Jeg vil - igen og igen, dag efter dag, år efter år.

Jeg vil være hudløs, åben og sansende.

Jeg vil -

Jeg vil ikke mere, kan ikke mere

og dog

måske alligevel.

Totalbevægelsen (den gymnastiske) i helt overført betydning, suset fra tyngden i armene, bølgerne i kroppen, løftet gennem de syv chakras, svævet i trinene; de andres åndedrag, varmen og koncentrationen.

Er alt dette fantastisk, er alt dette uundværligt - åh jo det er det.

Jeg vil altså alligevel.

Hvordan kan det være så fantastisk og uundværligt at lave sidebøjninger, haltehop, skulderryst, benstræk og kropsfigurer?

TJA
} 


\section{Et forsøg på en forklaring}

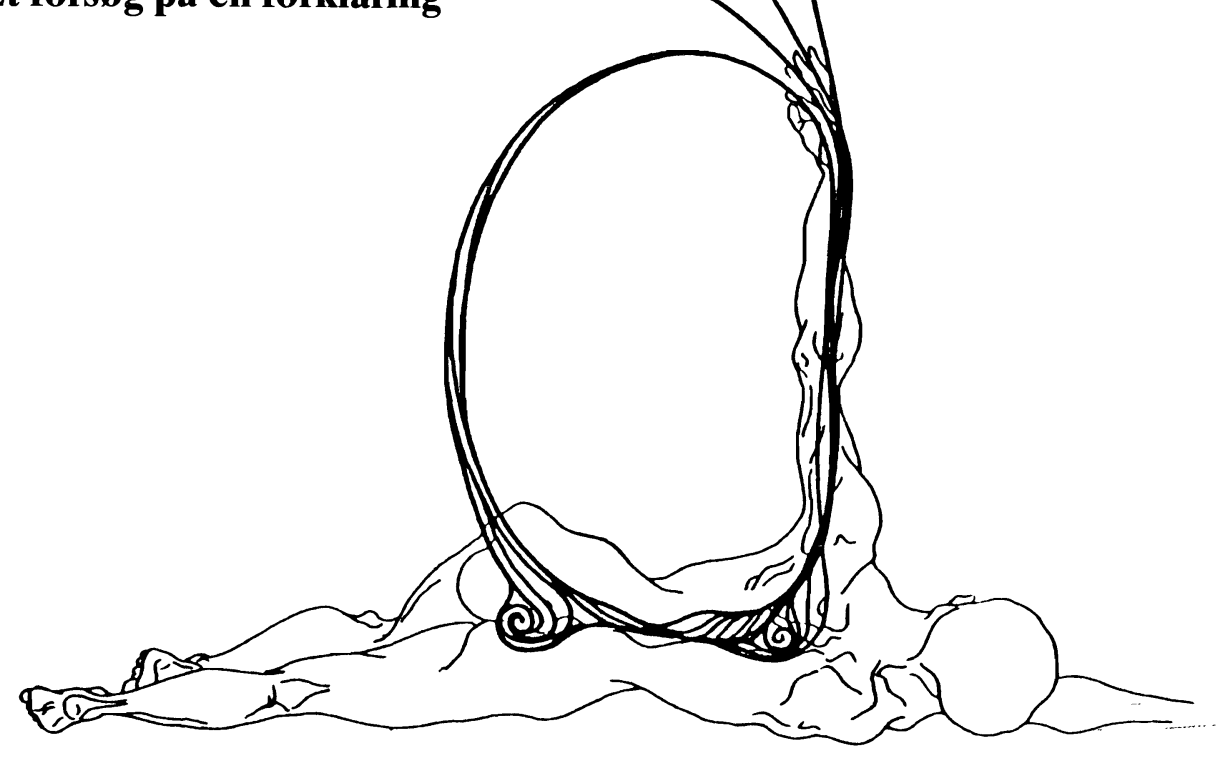

\section{Spor 1, oplevelsen}

Hvor sidder oplevelsen mon i grunden henne? Har vi specielle sanseorganer, der husker fra gang til gang og oven i købet har den evne at få mere og mere ud af bevægelsen og rytmen? For det er da fascinerende, at man aldrig bliver færdig med en bevægelse, et bevægelsesmønster, og at der i gentagelsen ligger en fordybelse. En fordybelse, der også flytter oplevelsen, sansningen til noget mere - jeg ved ikke af hvad - men ihvertfald så oplevelsen blive endnu sværere at glemme og endnu bedre at tænke tilbage på.

Som et billede, som et stykke musik?

Kunstens fællesnævnere.

Oplevelsen sidder ihvertfald et sted i kroppen (tag ikke fejl af det). Hovedet er kun til at danne ordene med.

For at livet og det, vi foretager os, skal være nærværende, må indeholdet ramme noget vigtigt, noget essentielt. Måske de små sanseorganer ved, hvad det er, der skal rammes. De er jo ihvertfald erfaringsafhængige og påvirkelige, de husker.

Er det det personlige sanseapparat, der gør, at vi bruger vores liv, vores krop forskelligt? At vi føler os tiltrukket af forskellige (idrætslige) muligheder?

Ja, og hvem styrer i det hele taget disse valg - genetikken, miljøet eller de kosmiske kræfter...?

Men midt i al det personlige er der så ikke også noget fælles, nogle fællesoplevelser? Noget universelt der går på tværs af køn og kultur, arbejde og alder?

Kender vi ikke alle til ekstasen, rytmen og den levendegjorte krop? 


\section{Afsporing}

Gymnastikken igen: Hvis disse fællesoplevelser karakteriserer gymnastikken, er det så forklaringen på, at gymnastikkens postulerede essens, æstetik og rationalitet, går ind og rammer stort set alle mennekser, passer til kropskulturens skabelon?

Jeg mener, et eller andet har jo ramt en mangfoldighed af mennesker (ihvertfald den kvindelige halvdel) $\mathrm{i}$ årenes løb. Er det mon disse skjulte universelle oplevelser, der får folk til at vende tilbage til gymnastiksalen år efter år, generation efter generation?

Men stop, for dette er jo kun den halve sandhed. Må man ikke i samme åndedrag huske, at også mange bliver frastødt og holder sig væk.

Gymnastikkens succes gennem tiderne, går den på konstateringen af, at der ikke var/ ikke er andre muligheder for fysisk aktivitet, intet idrætsligt, kropsligt, musisk alternativ?

For succesen kan vel ikke være på grund af gymnastikkens indforståethed, dens lukkede form, effektiviteten, de rationelle sving og forsideøvelserne, lærerstyringen, den fælles form og front? Uden plads og tid til spørgsmål, ingen skabelse, ingen åbenhed, ingen sanselighed, intet liv.

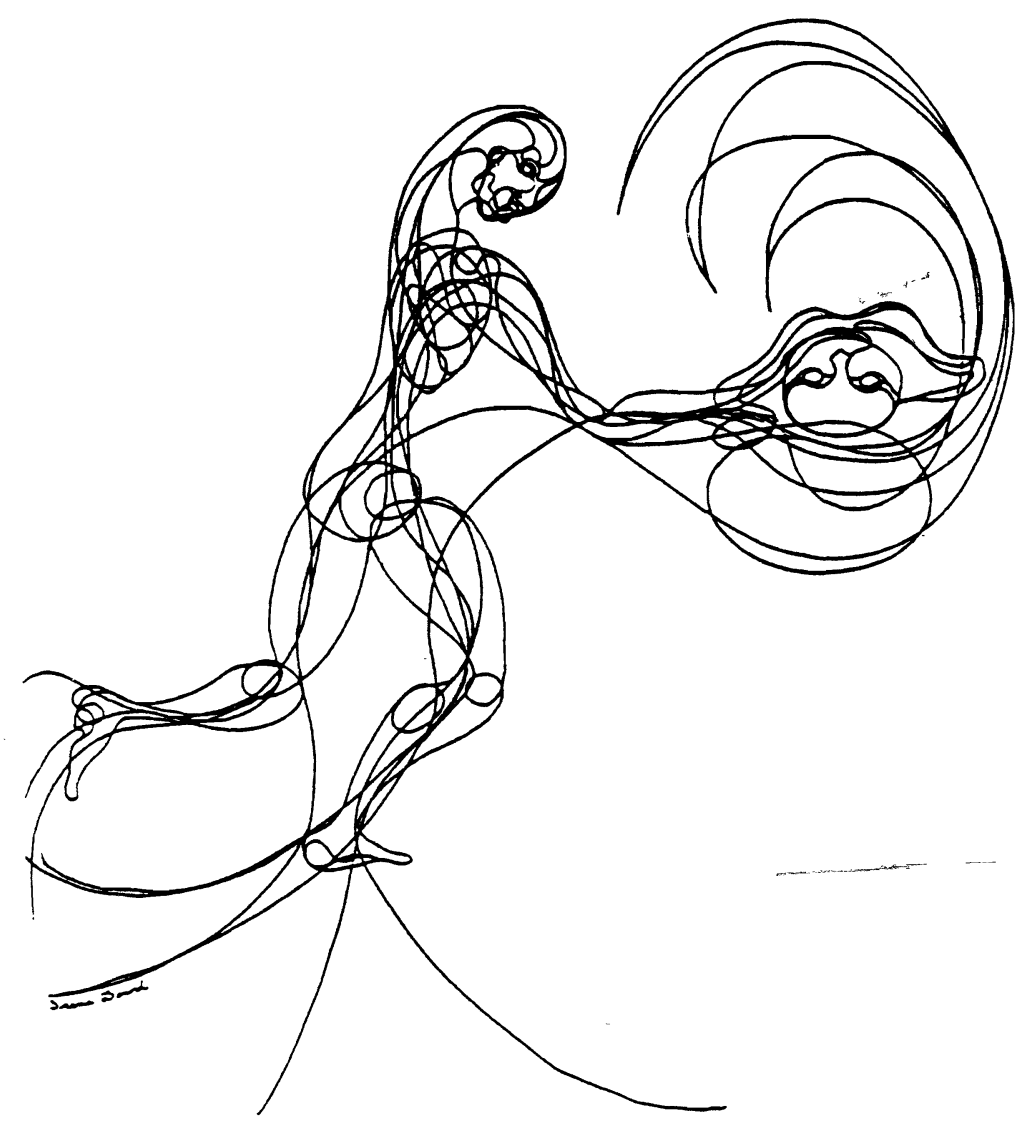




\section{Sporskifte}

\section{Spor 2, hvorfor:}

Hvorfor vandt den lukkede form?

Hvorfor forsvandt sanseligheden fra kropskulturen?

Hvad skete der fra dansens ekstase, fællesskabet, glæden og legen?

En kultivering-

javel.

Adlens prestige danse overfor folkets løssluppenhed.

Balletten, hoffets showdans, ballettens stilisering, den sikre vej til afgrunden forstået som den bedste og mest effektive kropsdressur, der endnu er set. Blev sanseligheden bevaret her? Er ballet sanseligt, er det æstetisk, er det kropsfornægtende?

Hvad er det?

Hvorfor fandt man mon i sin tid på at lave gymnastik?

På grund af en iboende trang til bevægelse, til formgivne øvelser og leg og ikke kun til arbejdsbevægelser? Lad os tro på, at det er en naturlig og medfødt trang, at vi har lyst til at bevæge os, at danse, synge og le, at lave idræt, at lave alsidigt kropsarbejde.

Det må så undre efter ovenstående, at man ikke forlængst er holdt op med at dyrke gymnastik!

Er det igen det manglende kropslige udbud, der spiller ind, eller er det manglen på fantasi? Eller er det fordi essensen, det det virkelig handler om, det der er det uundværlige - rytme og bevægelsesglæde - det når frem til sanseorganerne trods den ydre stive form...?

Oplevelsen findes et sted.

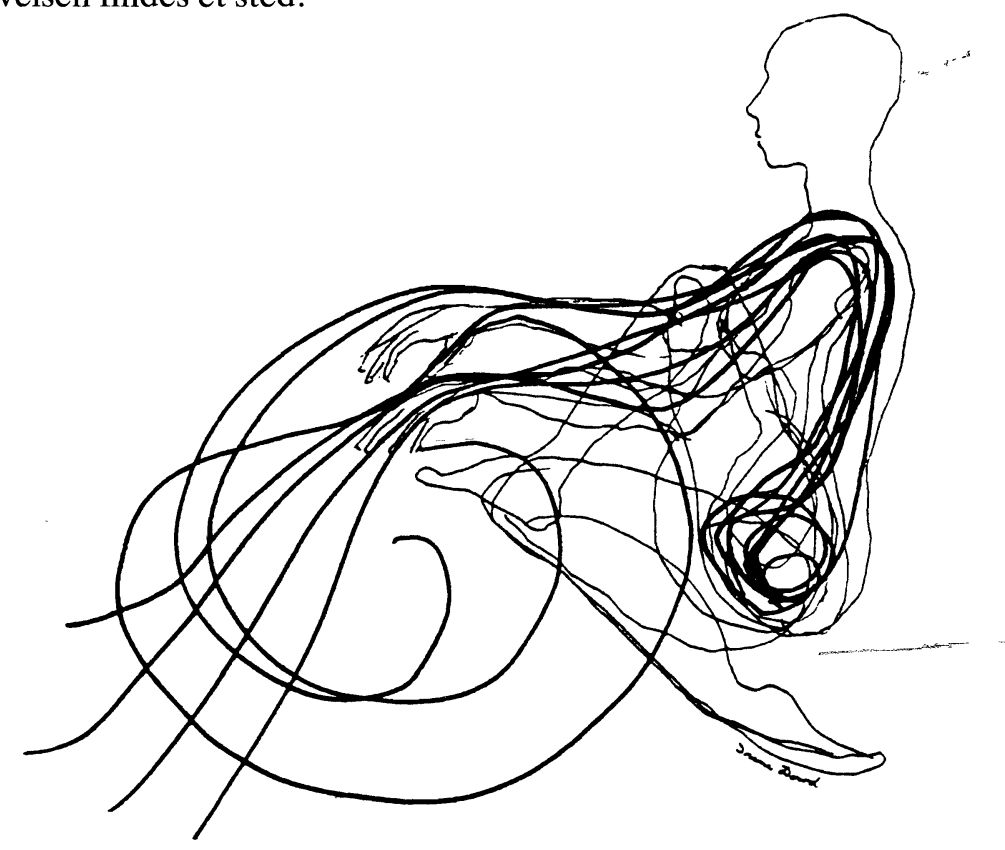




\section{Spor 3, på rette spor}

Visioner:

Gymnastikkens styrke og dens sårbarhed, men egenart, er, at her er det kroppen, der er genstanden/genstandsområdet.

Ingen streger, ingen bolde, ingen regler (ihvertfald tilsyneladende), kun legen med kroppens form og udtryk. Altså det er kun fantasien og vor kulturelle ballast, der sætter rammerne for gymnastikken, dens udvikling og trækplastre.

\section{Lad os sprænge rammerne}

Der er ingen bevægelsesregler og love, alt er tilladt, også det der ikke er effektivt og maksimerende i kropstræningens hellige navn. Det kønsspecifikke er ophævet, vi er alle yin og yang. Æstetik er sagen, jeg elsker det smukke og harmoniske, grimme bevægelser findes ikke, alt er ligeværdigt.

Brug musik til at gå i kødet med og ikke kun som tapet.

Gymanstikken kræver fra nu af another mindset, hvis den vil udvikle sig til noget magisk - og overleve.

Serierne er afskaffet som rækkeeksersits med samtidighed og vægt på ydre form. Det at skabe må nu være en nødvendighed, en trang til at bruge og udtrykke flere sider af sig selv.

Hvis man vil have med bevægelse at gøre må man være villig til at give noget af sig selv. Turde være åben, ærlig, politisk, sansende, være sig selv.

Den ydre form må ændres, stemningen, stilen, arbejdsformen (det pæádagogiske), så indholdet udover det træningsmæssige også bliver emotionelt. ligt.

Dermed kan man give andre noget, noget menneskeligt, noget mere helt, noget ær-

Kroppen, den skal opleves med hjertet ligesom resten af livet.

\section{Afrunding}

Den $\emptyset g e d e$ følsomhed eller opmærksomhed overfor kroppen kan ridses op i tre tendenser, tendenser vi kunne kalde kroppens iscenesættelse, nemlig:

Den terapeutiske tendens (den verbaliserede krop).

Den nydisciplinerende tendens (den dresserede krop).

Den kunstneriske tendens (den musiske krop).

Hvor disse tendenser skal eller kan føre hen, er ikke til at vide, men det jeg kunne $\emptyset$ nske mig at se fremover er ophævelsen af dualismen krop/ånd. At det kropslige var mindst lige så estimeret som det intellektuelle her på vore naturvidenskabelige og teknologiske breddegrader. At kroppen ikke kun er et alibi, at det er kropsligheden og ikke den intellektuelle iscenesættelse, der er målet. 
Da tror jeg sanseligheden er levendegjort, og den musiske krop (i den nye tids nye gymnastik) er tilbage i verdensbilledet.

Forandringen er sket.

\section{Inspiration}

Ballisager Olav: Gymnastik - idrættens dialektiske mulighed? Bavnebanke 1982.

Bertram Agnete: Hjemmegymnastik. Gyldendal 1927.

Capra Fritjof: Vendepunktet. Borgen 1986.

Den rytmiske faggruppe $\mathrm{DHL}$.

Langer Susanne K.: Feeling and Form, a theory of art. Scribner's sons. New York 1953.

Schmidt Lars-Henrik: Kroppen i focus - et essay om sport. Bavnebanke 1982. 